\title{
Influenza A Virus: Phylogeny of Neuraminidase Primers and Amplification of Polymerase Basic Protein 2 and Neuraminidase Genes
}

\author{
MARIA OMEGA ${ }^{1 *}$, RICHARD LAI $^{3}$, HANS HEINE $^{4}$, AND ROSS BARNARD 2
}

\begin{abstract}
${ }^{I}$ School of Biological Science, ${ }^{2}$ Biotechnology Department, School of Chemistry and Molecular Biosciences, Faculty of Science, The University of Queensland, St Lucia, Queensland, Australia 4072; ${ }^{3}$ BioChip Innovations Pty. Ltd., Brisbane, Queensland, Australia, ${ }^{4}$ CSIRO Livestock Industries, Australian Animal Health Laboratory, East Geelong, Victoria, Australia
\end{abstract}

\begin{abstract}
Influenza A virus is a highly contagious agent that causes bird flu. To date, 16 hemagglutinin (HA) and 9 neuraminidase (NA) subtypes are identified antigenically and can form any combinations or mutations with each other to confer non or low pathogenic to high pathogenic strains. Mutations in viral segments that are derived from avian isolates represent a novel subtypes to which human population is infected by influenza pandemics. In this work, polymerase basic protein 2 (PB2) gene segment of 8 different avian influenza subtypes were cloned to obtain more DNA samples for future work such as PB2 sequencing and to test HA primer annealing with PB2 gene. PCR amplification of NA gene segment of 3 different avian influenza subtypes was the second aim of this work to test primer universal for NA genes. Determination of the aligned sequences between 9 NA subtypes and NA primer PCR products was the second aim of this work, based on BLAST result homology $100 \%$ and phylogenetic trees of clustal
\end{abstract}

Keywords: Influenza A virus, phylogeny, amplification, PB2 gene, NA gene

Avian influenza pathogenic virus is a member of the family Orthomyxoviridae (Lamb et al. 1996; Lamb et al. 2007), divided into subtypes on the basis of two surface glycoproteins: hemagglutinin (HA) and neuraminidase (NA) (Hoffmann et al. 2000; Wright et al. 2001). Studies of pathogenicity showed that the optimal combination of HA and NA enabling the cleavage of HA was important. A balance in HA and NA activities is crucial; there must be enough HA activity to facilitate virus binding and enough NA activity to allow release of virus progeny (Mitnaul et al. 2000; Hulse et al. 2004). Therefore, HA and NA detection of influenza A virus have been done effectively using polymerase chain reaction (PCR) strategy, HA and NA universal primers to obtain information that may be related with the detection of viral infection, pathogenicity and host range of influenza A virus. In addition, phylogenetic lineages and BLAST homology results showed $100 \%$ between 9 NA viruses and NA primer PCR products which are essential to develop alignment and shared homology between subtypes.

The accumulation of mutations in viral segments such as polymerase basic protein 2 (PB2), M2 and NA genes can generate new chances to increase viral ability to infect species outside of natural reservoir and produce pathogenically various subtypes of virus. Therefore, it is important to identify these mutations to detect this viral infection and pathogenicity. For example, the mutation Ser64Ala in M2 protein gives rise to amantadine resistance (Barr 2005; Komadina et al. 2005; Russel et al. 2008). A glutamic acid to lysine substitution at position 627 in the PB2 protein (Hatta et al. 2001; Watanabe et al. 2008) has been associated with increased virulence of H5N1 viruses (Vesudevan et al. 2005; Alvarez et al. 2008). Moreover, Katz et al. (2000) analyzed that residues Thr-223 in the NA gene was unique to the H5N1 viruses of low pathogenicity and that Glu-355 in PB2 was found only in the human $\mathrm{H} 5 \mathrm{~N} 1$ viruses of low pathogenicity isolated from birds in Hong Kong in 1997. Mutations are also

"Corresponding author:, Phone: +61-7-38708673, Fax: +61-7-33651655, E-mail: omegadvm@hotmail.com associated with the antiviral drug resistance, Oseltamivir, such as the H5N1 strains with the H274T, R292K and N294S mutations (Moscona 2005; Moscona 2008; Peters et al. 2008).

\section{MATERIALS AND METHODS}

DNA Cloning of PB2 Gene Avian Influenza A Virus Subtypes: Preparation of Escherichia coli Strain DH5 $\alpha$ Competent Cells According to the Protocol Provided by Nishimura et al. (1990). Escherichia coli strain DH5 $\alpha$ was used as host cells for amplification of plasmid DNA. Bacteria cultures were diluted 1:100 in fresh LB broth with ampicillin and then incubated further at $37^{\circ} \mathrm{C}$ in a shaking incubator for overnight. $0.5 \mathrm{~mL}$ overnight culture was transferred into $50 \mathrm{~mL}$ solution $\mathrm{A}\left(\mathrm{LB}, \mathrm{MgSO}_{4} \mathrm{H}_{2} \mathrm{O}\right.$, glucose) in the flask at room temperature. The cultures were then incubated at $37^{\circ} \mathrm{C}$ with continuous shaking for about $3-4 \mathrm{~h}$ to reach a cell concentration of $8-12 \times 10^{8}$ cells $\mathrm{mL}^{-1}$ mid-log suspension culture indicating an $\mathrm{OD}_{600}$ of $0.8-1.2$. This culture was concluded when an optical density measured at $600 \mathrm{~nm}$ $\left(\mathrm{OD}_{600}\right)$ is 1.3. The culture was then transferred to microcentrifuge tubes and pelleted at $1500 \mathrm{~g}$ for $10 \mathrm{~min}$ at $4{ }^{\circ} \mathrm{C}$. The supernatant was discarded while the pellet was resuspended in $0.5 \mathrm{~mL}$ solution $\mathrm{A}$ and $2.5 \mathrm{~mL}$ solution $\mathrm{B}$ (glycerin, $\mathrm{PEG}, \mathrm{MgSO}_{4} \mathrm{H}_{2} \mathrm{O}$ ) and aliquoted in $0.1 \mathrm{~mL}$ each in $1.5 \mathrm{~mL}$ microcentrifuge tubes. These aliquots were then stored at $-80^{\circ} \mathrm{C}$.

Ligation. A total volume of $10 \mu \mathrm{L}$ ligation reaction consisted of $5 \mu \mathrm{L}$ rapid ligation buffer $2 \mathrm{x}, 1 \mu \mathrm{L}$ Taq DNA polymerase (Promega), and an appropriate volume of insert DNA such that pGEM-T essay vector: insert DNA ratio was approximately 1:2. Reactions were made up to final volumes using sterile distilled water and incubated at room temperature for an hour and then stored at $4{ }^{\circ} \mathrm{C}$ until transformation was carried out.

Heat Shock Transformation. For transformation, $100 \mu \mathrm{L}$ competent $E$. coli strain DH5 $\alpha$ cells were mixed with 10 $\mu \mathrm{L}$ A-tailed ligation product (PB2 gene of H1N9 or H3N8 in $\mathrm{p}-\mathrm{GEM}-\mathrm{T}$ easy vector) and chilled in ice for $10 \mathrm{~min}$ prior to heat shock treatment in a $42{ }^{\circ} \mathrm{C}$ water bath for $1 \mathrm{~min}$. The cells 
were immediately placed back in ice for another $20 \mathrm{~min}$. The reaction mixture was then incubated in $1 \mathrm{~mL}$ prewarm $\mathrm{LB}$ at $37^{\circ} \mathrm{C}$ for $1 \mathrm{~h}$ in a falcon tube. $100 \mu \mathrm{L}$ bacterial suspension was spread per preheated $100 \mu \mathrm{g} \mathrm{mL}^{-1}$ of ampicillin selective LB agar plates that were added with $100 \mu \mathrm{L}$ IPTG and $20 \mu \mathrm{L}$ X-gal for overnight incubation at $37^{\circ} \mathrm{C}$. The remaining bacterial suspension was also spread per LB agar plates and incubated overnight at $37^{\circ} \mathrm{C}$.

Screening of Positive Colonies. p-GEM-T easy plasmid (Promega) was the vector used for all cloning work. Putative transformants containing this vector with the desired insert were identified based on blue/white screening. Putative positive colonies were identified as white colonies and approximately 10 white colonies per plate were isolated using sterile pipette tip per colony. We did not find any white colonies that grew on agar plates because the ligation and transformation of incompetent $E$. coli $\mathrm{dH} 5 \alpha$ cells were failed. Consequently, we repeated the ligation and transformation with another type of competent cells such as E. coli Top10 (Invitrogen) cells.

Ligation. A total volume of $10 \mu \mathrm{L}$ ligation reaction consisted of $5 \mu \mathrm{L}$ rapid ligation buffer $2 \mathrm{x}, 1 \mu \mathrm{L}$ Taq DNA polymerase (Promega), and an appropriate volume of insert DNA such that pGEM-T essay vector: insert DNA ratio was approximately $1: 2$. Reactions were made up to final volumes using sterile distilled water and incubated at $4{ }^{\circ} \mathrm{C}$ for overnight and then, transformation was carried out after successful complementary annealing of vector 3'- thymadine (T)overhangs with deoxyadenosine (A)-tailed PCR inserts enables ligation.

Rapid Chemical Transformation. For transformation, $50 \mu \mathrm{L}$ competent $E$. coli Top10 (Invitrogen) cells were mixed with $10 \mu \mathrm{L}$ each A-tailed ligation product (PB2 gene of H5N3, H6N5, H7N7, H11N6, H12N9, or H15N9 shown in table 1, in $\mathrm{p}$-GEM-T easy vector) and chilled in ice for $5 \mathrm{~min} .10 \mu \mathrm{L}$ of cells was spread on a pre-warm LB agar plate containing $100 \mu \mathrm{g} \mathrm{mL} \mathrm{L}^{-1}$ ampicillin, $100 \mu \mathrm{L}$ IPTG and $20 \mu \mathrm{L} \mathrm{X}$-gal. The remaining $(50 \mu \mathrm{L})$ of cells was also spread on another $\mathrm{LB}$ agar plate. These agar plates were incubated overnight at $37^{\circ} \mathrm{C}$.

Screening of Positive Colonies. p-GEM-T easy plasmid (Promega) was the vector used for all cloning work. Putative transformants containing this vector with the desired insert were identified based on blue/white screening. Putative positive colonies were identified as white colonies and approximately 10 white colonies per plate were isolated using sterile pipette tip per colony. Each tip was immersed in $5 \mathrm{~mL}$ falcon tubes containing $2 \mathrm{~mL}$ LB broth supplemented with $100 \mu \mathrm{g} \mathrm{mL}^{-1}$ ampicillin. The bacterial suspension was grown overnight in a $37^{\circ} \mathrm{C}$ shaking incubator. Positive colonies are determined with plasmid purification followed by nanodrops

Table 1 Polimerase basic protein 2 (PB2) genes of Influenza A Virus Subtypes

\begin{tabular}{llc}
\hline Subtype & \multicolumn{1}{c}{ Avian species } & Reference \\
\hline H1N9 & A/Shelduck/WA/1757/78 & $8705-22-1100$ \\
H3N8 & A/Avian/669/WA/78 & $8510-15-1215$ \\
H5N3 & A/Shearwater/Aust/75 & $8508-16-1600$ \\
H6N5 & A/Shearwater/Aust/72 & $8507-10-1200$ \\
H7N7 & A/Chicken/Victoria/1/85 & $8507-31-1430$ \\
H11N6 & A/Tern/Aust/75 & $8610-15-1330$ \\
H12N9 & A/RNStint/WA/5754/84 & $9010-05-1330$ \\
H15N9 & A/Shelduck/WA/1762/79 & $9008-18-1000$ \\
\hline
\end{tabular}

spectrophotometer, restriction digestion and these clones are cryopreserved at $-20^{\circ} \mathrm{C}$ until use.

Plasmid Purification. The alkaline method was used for purification of plasmid DNA using the QIAprep Spin MiniPrep Kit (Qiagen). Briefly, putative transformants (white colonies) were cultured in $2 \mathrm{~mL}$ LB broth supplemented with $100 \mu \mathrm{g} \mathrm{mL} \mathrm{m}^{-1}$ ampicillin for overnight. Bacterial culture grew at $37^{\circ} \mathrm{C}$ in a shaking incubator Plasmid extraction was carried out in accordance with the manufacturer's recommendation. The eluted DNA is stored in $-20^{\circ} \mathrm{C}$ freezer.

Determination of DNA Concentration. The absorbance of DNA was measured at $260 \mathrm{~nm}\left(\mathrm{~A}_{260}\right)$ using a Nanodrop Untraviolet/Visible Spectrophotometer. DNA concentrations were estimated with the assumption that $50 \mu \mathrm{g} \mathrm{mL} \mathrm{m}^{-1}$ double stranded DNA has an absorbance at $\mathrm{A}_{260}$ of 1 . The Nanodrop spectrophotometer was utilized in all absorbance and DNA/ RNA concentration determination. $2 \mu \mathrm{L}$ each sample of eluted DNA was dropped and measured at $\mu=260$, DNA -50 using Spectrophotometer program of ND1000 V3.1.2, nucleic acid. Eluted DNA was pure if 260/280 is 1.8-2.0. The concentration of eluted DNA was also measured to obtain information in DNA dilution.

Restriction Endonuclease Digestion of plasmid DNA. Restriction endonuclease digests were performed with a $20 \mu \mathrm{L}$ digestion reaction mix consisting $2 \mu \mathrm{L} \mathrm{H}$ buffer $10 \mathrm{x}$ (Roche) and an appropriate amount of DNA such as restriction enzyme: plasmid DNA ratio was approximately 1:10. Reactions were made up to final volumes using sterile distilled water. The enzyme EcoRI was used in all restriction digests and thus, the reaction mix was carried out using the PCR cycling program $\left(37^{\circ} \mathrm{C}\right.$ for $90 \mathrm{~min}, 65^{\circ} \mathrm{C}$ for $15 \mathrm{~min}$ and $4{ }^{\circ} \mathrm{C}$ until end). Digested products were visualized on $2 \%$ agarose gels.

Agarose Gel Electrophoresis of DNA. Agarose gel electrophoresis of DNA was typically run on a $1.5-2 \%(\mathrm{w} / \mathrm{v})$ agarose gel stained with ethidium bromide in $1 \mathrm{x}$ TAE buffer. DNA samples were combined with $6 x$ loading dye. The size of DNA fragments were determined by comparison to a standard 1 kb DNA Ladder Mix or 2 kb DNA Hyperladder II, visualized by ultra violet illumination.

Polymerase Chain Reaction Amplification of NA Genes. PCR involves repetitive thermal cycling composed of three steps: i, melting temperature $\left(94^{\circ} \mathrm{C}\right)$ to denaturate DNA; ii, annealing to cool the mixture (step down temperature from $56-42{ }^{\circ} \mathrm{C}$ ) allowing NA primers to anneal target DNA sequences; and iii, extension to elongate DNA with dNTP by polymerase. PCR amplification of 3 subtypes of Avian NA genes of Influenza virus subtypes (H6N5, H7N7 and H12N9) were essential as a separate step following cDNA composition via RT-PCR due to limited starting volumes of RNA. Amplification was carried out in a $50 \mu \mathrm{L}$ reaction consisting

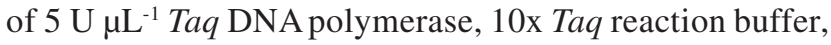
$50 \mathrm{mM} \mathrm{MgCl}, 10 \mathrm{mM}$ dNTP mix, $100 \mu \mathrm{M}$ of each forward and reverse NA primer, an appropriate volume of distilled water and template DNA as optimized from previously obtained RT cDNA. PCR reaction was carried out using the MasterCycler PCR ${ }^{\circledR}$ Machine (Eppendorf, QLD). PCR products were stored at $-20{ }^{\circ} \mathrm{C}$ (freezer) and were also visualized on $1.5 \%$ agarose gels. 
Extraction of DNA Fragments from Agarose Gels. The MinElute Gel Extraction Kit Protocol using a microcentrifuge (Qiagen) was utilized for the isolation of specific DNA fragments from agarose gels. Experimentation was performed according the manufacturer's instructions. Generally, gel extractions were performed to elute DNA from gels contained desired DNA bands of PCR products with an appropriate amount of gel such that gel: buffer QG ratio was approximately $1: 3$ and gel: isopropanol was approximately $1: 1$, and added another buffer (PE) and distilled water. To elute more DNA, second clean up was carried out by adding distilled water to the spin column. Eluted DNA was stored at $-20{ }^{\circ} \mathrm{C}$.

Blast Searches and Phylogenetic Tree Development and Basic Local Alignment Search Tool (BLAST) Searches. Sequence data was compared to GenBank DNA Database using BLASTn searches to determine the alignment ( $\%$ identity) between NA primers (table 2 ) and all virus origin (virus nucleotide database) using the National Centre for Biotechnology Information (NCBI) BLAST network server available from http://www.ncbi.nlm.nih.gov/

Phylogenetic Tree Development. Phylogenetic trees were developed to test variability for regions of sequence bounded by PCR primers. 3 pairs of NA primers ( $5 \mathrm{~F}$ and $10 \mathrm{R}, 8 \mathrm{~F}$ and $10 \mathrm{R}, 10 \mathrm{~F}$ and $11 \mathrm{R}$ ) were aligned against a selection of genbank database sequences using ClustalX v 1.83 available from http://bips.u strasbg.fr/Documentation/ClustalX. Sequences based on Influenza Sequence Databasehttp://www.flu.lanl.gov/ and NA primer sequences were uploaded as FASTA files and a preliminary complete alignment was done. Aligned sequences were viewed, and then sequences were cropped to do alignment on sequence range defined by primers. Cropped sequences were realigned and saved as a new FASTA files. A region sequences defined by primers was aligned to draw bootsrapped $\mathrm{NJ}$ trees and to open the trees using Treeview. 1000 bootstrap values were carried out and can be shown at the nodes of the trees shown in Fig 1, 2, and 3.

Mutations in NA Primer PCR Products. Mutations in the NA primer products were specifically targeted for research in this project. Mutations positions of the NA primers have been reported to increase infection, pathogenicity and resistance to antiviral drugs. Thereby, it is essential to determine any mutations that occur clinically in NA primer PCR products.

\section{RESULTS}

Amplification of PB2 Gene Segment DNA via Cloning. DNA products generated by PCR digestion showed plasmid DNA product length of $3015 \mathrm{bp}$ and insert DNA clone product length of $986 \mathrm{bp}$. Lane 1 consisted of $2 \mathrm{~kb}$ DNA Hyperladder II. Lane 2 consisted of positive control, contained plasmid
DNA without EcoRI enzyme. Lane 3 showed negative control, contained EcoRI enzyme without plasmid DNA. Lane 4-13 each denoted p-GEM-T easy vector DNA length product of $3015 \mathrm{bp}$ and H5N3/A/Shearwater/Aust/75 PB2 full length product of $986 \mathrm{bp}$, clones 1-10.

DNA products generated by PCR digestion showed plasmid DNA product length of $3015 \mathrm{bp}$ and insert DNA clone product length which was expected to be $986 \mathrm{bp}$. Lane 1 consists of $2 \mathrm{~kb}$ DNA Hyperladder II. Lane 2 shows negative control, contains EcoRI enzyme ithout plasmid DNA. Lane 3-12 each denotes p-GEM-T easy vector DNA length product of $3015 \mathrm{bp}$ and H6N5/A/Shearwater/Aust/72 PB2 full length product of $986 \mathrm{bp}$, clones 1-10.

DNA products generated by PCR digestion showed plasmid DNA product length of $3015 \mathrm{bp}$ and insert DNA clone product length of $986 \mathrm{bp}$. Lane 1 consists of $2 \mathrm{~kb}$ DNA Hyperladder II. Lane 2 shows negative control, contains EcoRI enzyme without plasmid DNA. Lane 3-12 each denotes p-GEM-T easy vector DNA length product of $3015 \mathrm{bp}$ and H11N6/A/Tern/Aust/75 PB2 full length product of $986 \mathrm{bp}$, clones 1-10.

DNA products generated by PCR digestion showed plasmid DNA product length of $3015 \mathrm{bp}$ and insert DNA clone product length which was expected to be $986 \mathrm{bp}$. Lane 1 consists of $2 \mathrm{~kb}$ DNA Hyperladder II. Lane 2 consisted of positive control, contained plasmid DNA without EcoRI enzyme. Lane 3 showed negative control, contained EcoRI enzyme without plasmid DNA. Lane 4-13 each denoted p-GEM-T easy vector DNA length product of $3015 \mathrm{bp}$ and H15N9/A/Shelduck/WA/1762/79 PB2 full length product of $986 \mathrm{bp}$, clones 1-10.

DNA products generated by PCR digestion showed plasmid DNA product length of $3015 \mathrm{bp}$ and insert DNA clone product length of $986 \mathrm{bp}$. Lane 1 consisted of $2 \mathrm{~kb}$ DNA Hyperladder II. Lane 2 showed negative control, contained EcoRI enzyme without plasmid DNA. Lane 3 and 7 each consisted of positive control, contained plasmid DNA without EcoRI enzyme. Lane 4-5 each denoted p-GEM-T easy vector DNA length product of 3015 bp and H7N7/A/Chicken/ Victoria/1/85 PB2 full length product of $986 \mathrm{bp}$, clones 1-2. Lane 6 showed only p-GEM-T easy vector DNA length product of $3015 \mathrm{bp}$, without any insert DNA. Lane 8-10 depicted p-GEM-T easy vector DNA length product of 3015 bp and H12N9/A/RNStint/WA/5754/84 PB2 full length product of $986 \mathrm{bp}$, clones 5, 9 and 10 .

DNA products generated by PCR digestion showed plasmid DNA product length of $3015 \mathrm{bp}$ and insert DNA clone product length which was expected to be $986 \mathrm{bp}$. Lane 1 consisted of $2 \mathrm{~kb}$ DNA Hyperladder II. Lane 2 showed negative control, contained EcoRI enzyme without plasmid DNA. Lane 3 consisted of positive control, contained plasmid DNA

Table 2 Neuraminidase (NA) Primers

\begin{tabular}{lllcrr}
\hline ID & \multirow{2}{*}{ Oligo } & \multicolumn{1}{c}{ Sequence 5' - 3' } & \multicolumn{3}{c}{ Product (bp) } \\
\cline { 3 - 6 } & & & Start & End & Length \\
\hline 407788 & 8F & GRA CHC ARG ART C5K MRT G & 690 & 909 & 219 \\
407793 & 10F & TGY AGR GAY AAY TGG M55 GG & 890 & 1243 & 353 \\
407785 & 5F & CAY DS5 AAT GR5 ACM RT5 MA5 GA & 449 & 909 & 460 \\
407787 & $10 \mathrm{R}$ & CC5 5KC CAR TTR TCY CTR CA & 690 & 909 & 219 \\
407792 & $11 \mathrm{R}$ & CCD ASA RTA 5CC 5GA CCA RT & 890 & 1243 & 353 \\
\hline
\end{tabular}




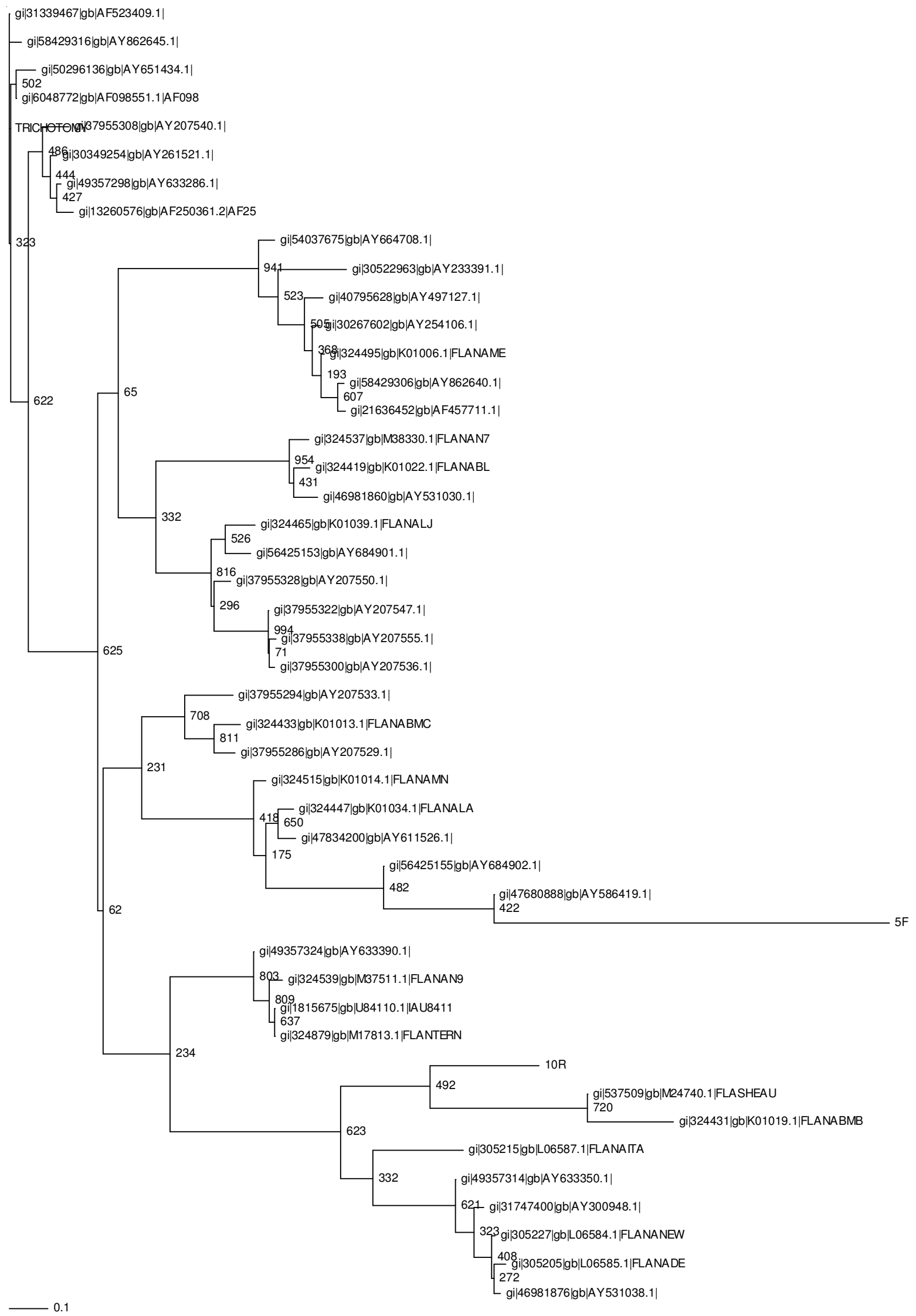

Fig 1 Phylogenetic Tree including 5F, 10R NA Primers and virus subtypes. 


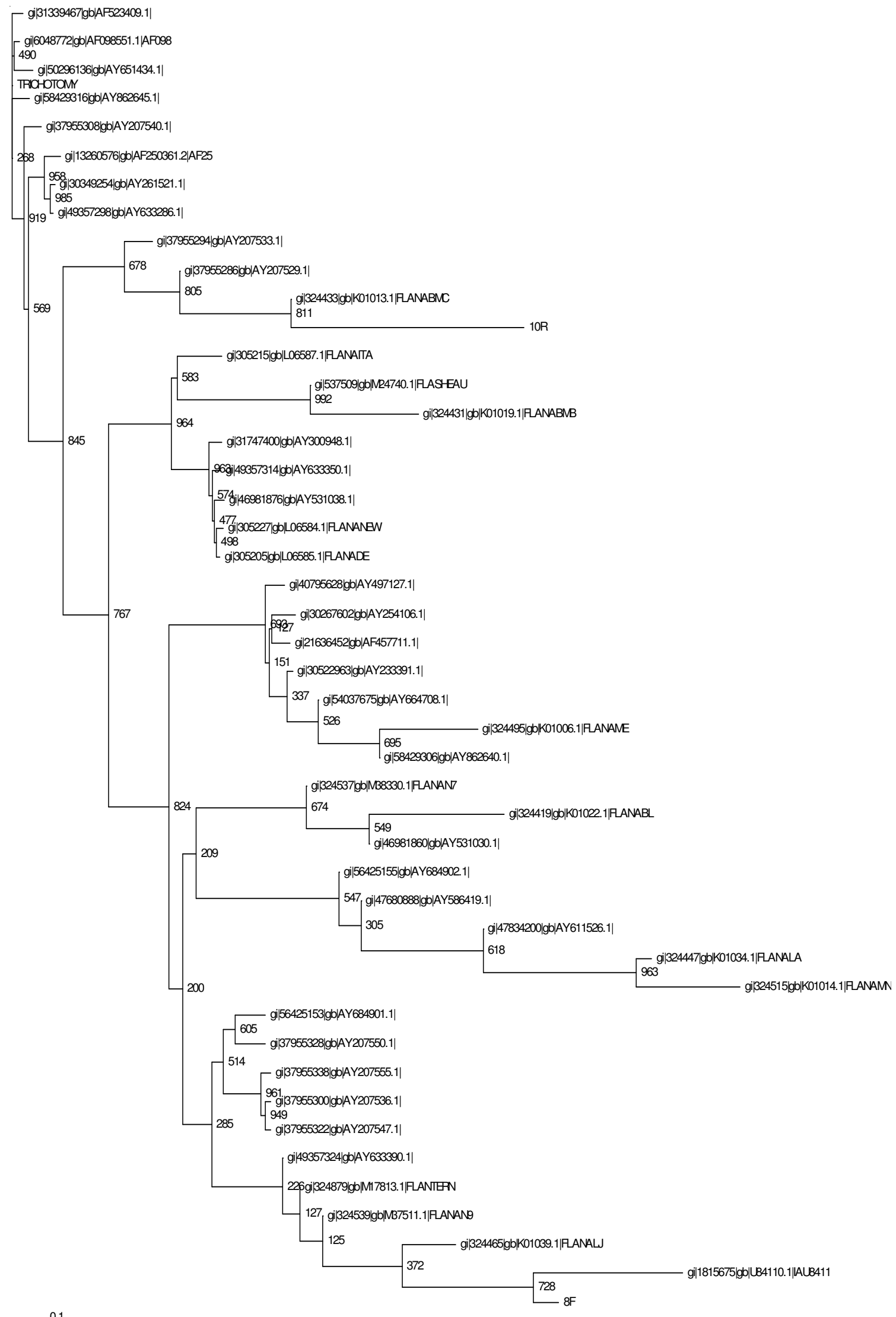

Fig 2 Phylogenetic Tree including 8F, 10R NA primers and virus subtypes. 


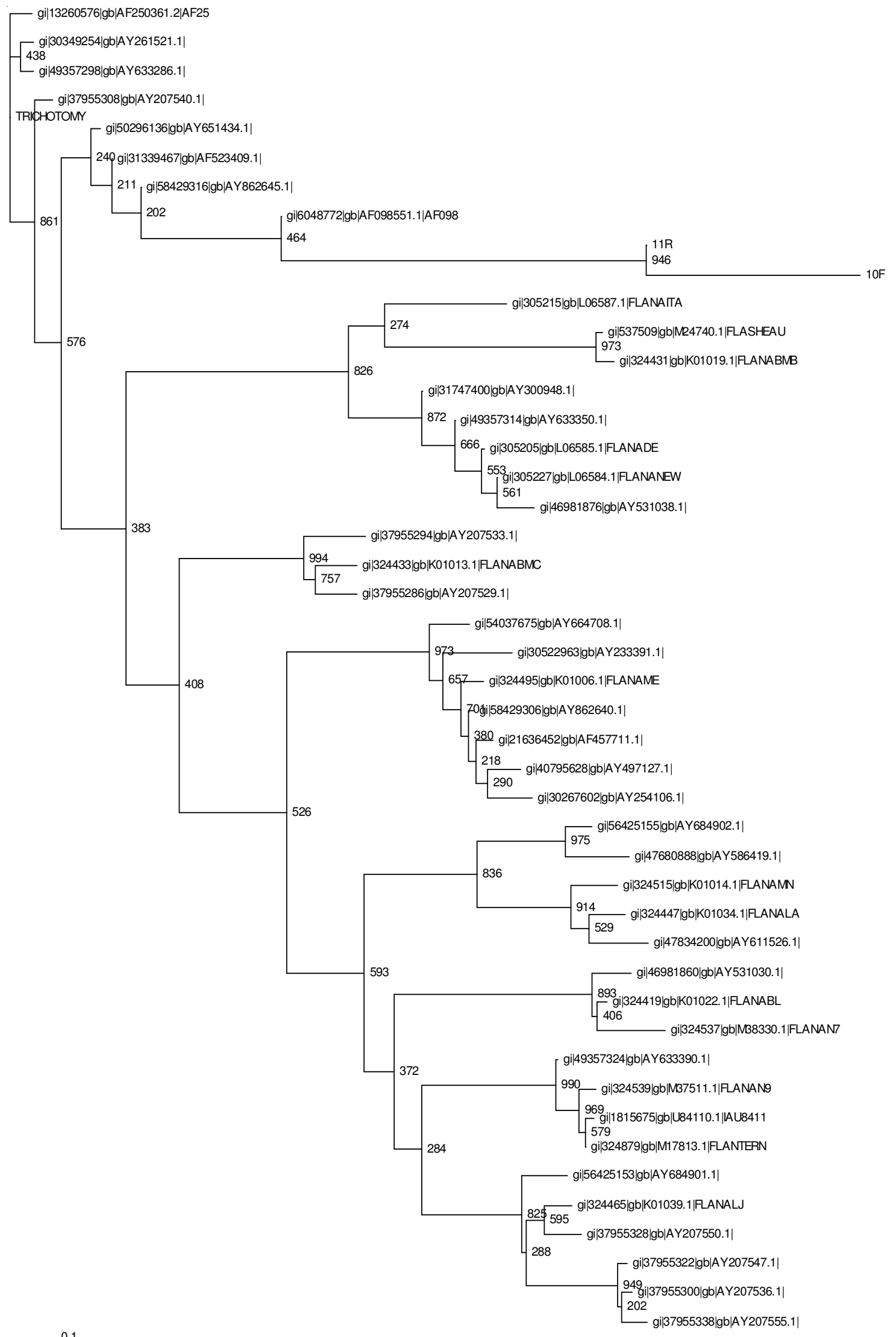

Fig 3 Phylogenetic Tree including 10F, 11R NA Primers and virus subtypes. 
without EcoRI enzyme. Lane 4-13 each denoted p-GEM-T easy vector DNA length product of 3015 bp and H7N7/A/ Chicken/Victoria/1/85 PB2 full length product of $986 \mathrm{bp}$, clones $1-10$.

DNA products generated by PCR digestion showed plasmid DNA product length of $3015 \mathrm{bp}$ and insert DNA clone product length which was expected to be $986 \mathrm{bp}$. Lane 1 consisted of $2 \mathrm{~kb}$ DNA Hyperladder II. Lane 2 showed negative control, contained EcoRI enzyme without plasmid DNA. Lane 3 consisted of positive control, contained plasmid DNA without EcoRI enzyme. Lane 4-9 each denoted only p-GEM-T easy vector DNA length product of 3015 bp and without any insert DNA clones 1-6.

Determination of PB2 Gene Concentration. Plasmid purification using QIAprep Spin MiniPrep Kit (Qiagen) followed by restriction endonuclease and gel analysis (Fig 49) indicated that ligations was highly efficient with most putative PB2 colonies proving to be positive. The presence of PB2 genes in plasmids of isolated clones were confirmed by DNA purity and concentration via Nanodrop Ultraviolet (UV)/Visible Spectrophotometer. DNA purity was estimated with the assumption that pure DNA sample has an absorbance at $\mathrm{A}_{260 / 280}$ of 1.8-2.0. The results showed PB2 gene H1N9 clone 7, PB2 gene H6N5 clone 3 and 6, PB2 gene H15N9 clone 1, $\mathrm{PB} 2$ gene $\mathrm{H} 5 \mathrm{~N} 3$ clone 5 and $\mathrm{PB} 2$ gene $\mathrm{H} 7 \mathrm{~N} 7$ clone 5 were less than 1.8 indicating the DNA samples were not pure because of protein contaminations during plasmid DNA purification procedures while the other clones were pure as expected to be between 1.8 and 2.0 (Table 4).

PCR Amplification of NA Genes. To generate neuraminidase (NA) gene segment samples via PCR amplification (Table 5) was essential for analysis of primer annealing, mutations and phylogeny work. The genes were

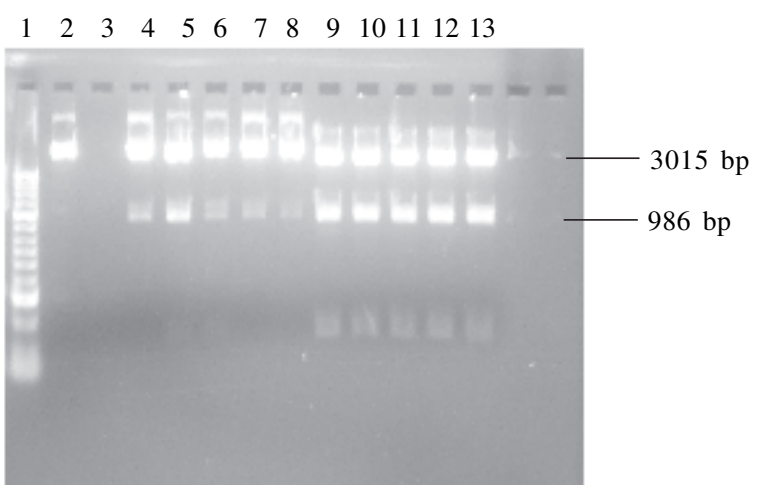

Fig 4 Analysis of H5N3 PB2 gene segment DNA PCR products.
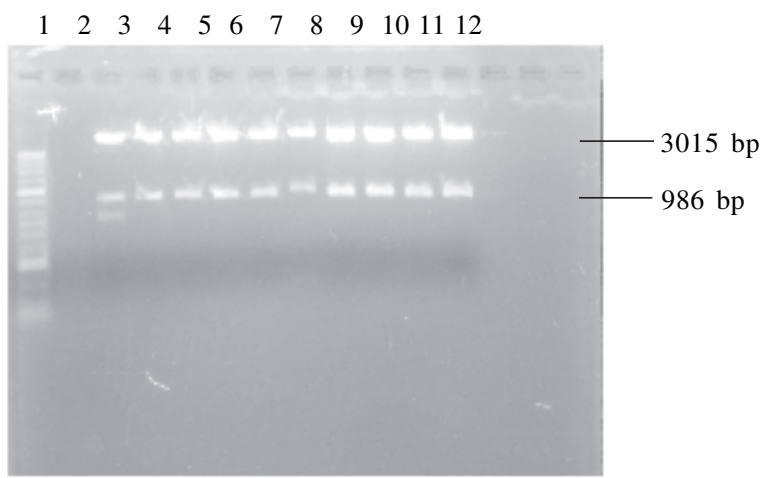

Fig 5 Analysis of H6N5 PB2 gene segment DNA PCR product. need to be isolated, amplified, analyzed then further work including sequencing.

Extraction of DNA Fragments from Agarose Gels. The MinElute Gel Extraction Kit Protocol using a microcentrifuge (Qiagen) was utilized for the isolation of specific DNA

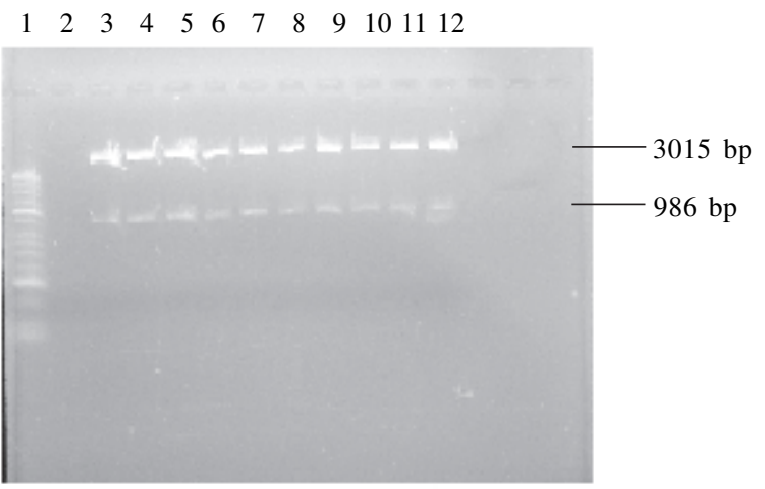

Fig 6 Analysis of H11N6 PB2 gene segment DNA PCR product.

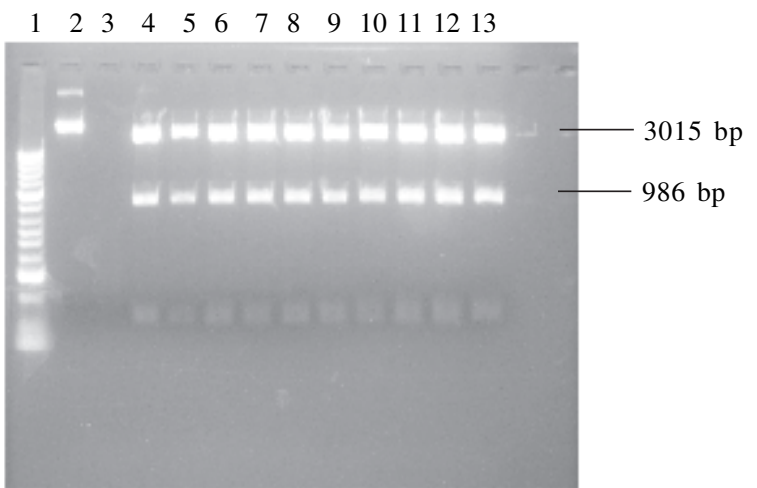

Fig 7 Analysis of H15N9 PB2 gene segment DNA PCR product.

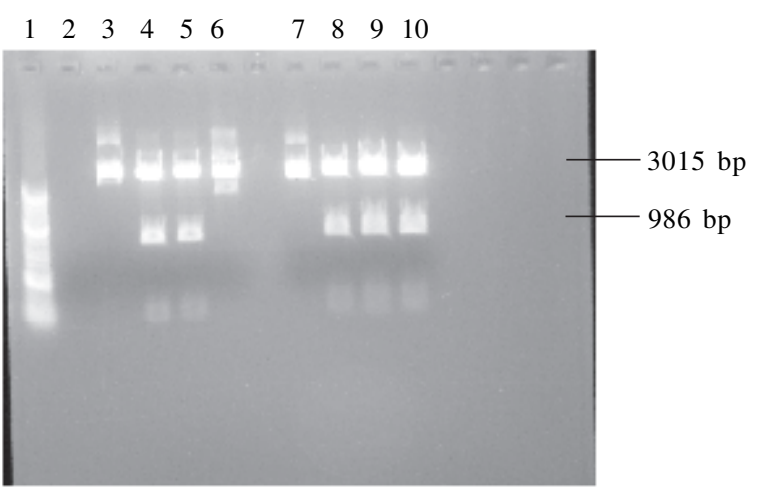

Fig 8 Analysis of H7N7 and H12N9 PB2 gene segment DNA PCR product.

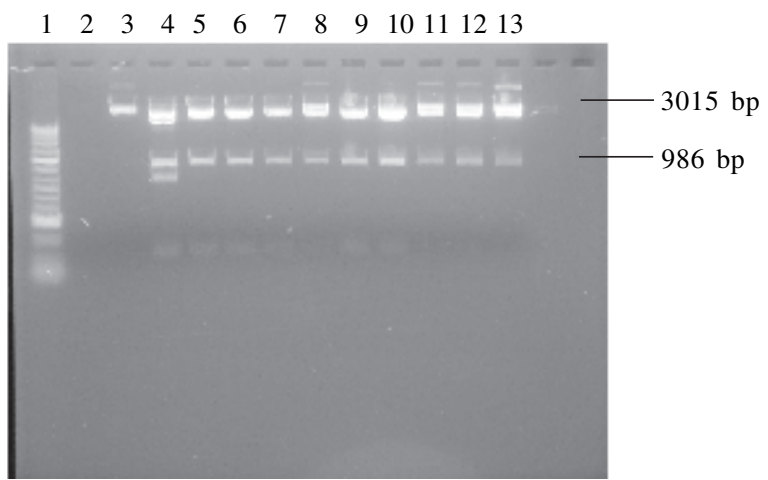

Fig 9 Analysis of H7N7 PB2 gene segment DNA PCR product. 
Table 4 DNA purity and concentration of PB2 gene segment clones

\begin{tabular}{|c|c|c|}
\hline CLONE $(n=80)$ & DNA PURITY $\quad(260 / 280=1.8-2.0)$ & DNA CONCENTRATION $\left(\mathrm{ng} \mu \mathrm{L}^{-1}\right)$ \\
\hline $\begin{array}{l}\text { PB2, H1N9 clones } 2,3,4,5 \text {, } \\
6,7,9,10\end{array}$ & $\begin{array}{l}\text { Clones } 2,3,4,5,6,9,10 \text { are good except } \\
\text { clone } 7(1.38) \text {. }\end{array}$ & $\begin{array}{l}\text { Clone } 2 \text { is the lowest }(81.2) \text {, clone } 7 \\
\text { is the highest }(119.2)\end{array}$ \\
\hline PB2, H3N8 clones 1-9 & H3N8 clones 1-9 are all good. & $\begin{array}{l}\text { H3N8 clone } 2 \text { is the lowest }(109.9) \text {, } \\
\text { clone } 9 \text { is the highest }(140.3) .\end{array}$ \\
\hline PB2, H6N5 clones $1,2,3,4,6$ & H6N5 clones 1-4 are good except clone 6 & H6N5 clone 6 is the lowest $(14.0)$, \\
\hline $\mathrm{PB} 2, \mathrm{H} 6 \mathrm{~N} 5$ clones $1-10$ & $\begin{array}{l}(1.71) \text {. } \\
\text { H6N5 clones } 1,2,4-10 \text { are good except } \\
\text { clone } 3(1.57) \text {. }\end{array}$ & $\begin{array}{l}\text { clone } 1 \text { is the highest }(247.1) \text {. } \\
\text { H6N5 clone } 1 \text { is the lowest }(63.4) \text {, } \\
\text { clone } 10 \text { is the highest }(201.2) \text {. }\end{array}$ \\
\hline PB2, H11N6 clones $1-10$ & H11N6 clones $1-10$ are all good. & $\begin{array}{l}\text { H11N6 clone } 8 \text { is the lowest }(52.4) \text {, } \\
\text { clone } 3 \text { is the highest }(92.1) .\end{array}$ \\
\hline PB2, H15N9 clones $1-10$ & $\begin{array}{l}\text { H15N9 clones } 2-10 \text { are good except clone } \\
1(1.78) \text {. }\end{array}$ & $\begin{array}{l}\text { H15N9 clone } 2 \text { is the lowest }(74.2) \text {, } \\
\text { clone } 9 \text { is the highest (121.8). }\end{array}$ \\
\hline PB2, H5N3 clones $1-10$ & $\begin{array}{l}\text { H5N3 clones } 1-4,6-10 \text { are good except } \\
\text { clone } 5(1.75)\end{array}$ & $\begin{array}{l}\text { H5N3 clone } 3 \text { is the lowest }(86.8) \text {, } \\
\text { clone } 6 \text { is the highest }(153.5) \text {. }\end{array}$ \\
\hline PB2, H7N7 clones 1-3 & H7N7 clones 1, 3 are good except clone 2 & H7N7 clone 2 is the lowest (95.8), \\
\hline $\mathrm{PB} 2, \mathrm{H} 7 \mathrm{~N} 7$ clones $1-10$ & $\begin{array}{l}(1.78) \\
\text { H7N7 clones } 1-10 \text { are all good. }\end{array}$ & $\begin{array}{l}\text { clone } 1 \text { is the highest }(115.2) \text {. } \\
\text { H7N7 clone } 8 \text { is the lowest }(94.4) \text {, } \\
\text { clone } 7 \text { is the highest }(155.1)\end{array}$ \\
\hline PB2, H12N9 clones 5,9,10 & H12N9 clones $5,9,10$ are all good. & H12N9 clone 5 is the lowest (98.9), \\
\hline PB2, H12N9 clones 1-6 & H12N9 clones 1-6 are all good. & $\begin{array}{l}\text { clone } 10 \text { is the highest }(124.4) \text {. } \\
\text { H12N9 clone } 4 \text { is the lowest }(29.3) \text {, } \\
\text { clone } 6 \text { is the highest }(150.9) \text {. }\end{array}$ \\
\hline
\end{tabular}

Table 5 Expected bands for PCR products

\begin{tabular}{|c|c|c|c|}
\hline Sample to run & Pair of Primers & Product length $(\mathrm{bp})$ & $\begin{array}{c}\text { Results from gels } \\
\text { (figures were unavailable) }\end{array}$ \\
\hline H6N5A/Shearwater/Aust/72 & $5 F+10 R$ & 460 & 3 Bands: $200 \mathrm{bp}, 300 \mathrm{bp}, 400 \mathrm{bp}$ \\
\hline H6N5A/Shearwater/Aust/72 & $8 \mathrm{~F}+10 \mathrm{R}$ & 219 & 219 bp \\
\hline H6N5A/Shearwater/Aust/72 & $10 \mathrm{~F}+11 \mathrm{R}$ & 353 & $353 \mathrm{bp}$ \\
\hline H6N5A/Shearwater/Aust/72 & $8 F+9 R$ & 169 & $170 \mathrm{bp}$ \\
\hline $\begin{array}{l}\text { H7N7A/Chicken/Victoria/1/ } \\
\text { 85(POSITIVE CONTROL) }\end{array}$ & $10 \mathrm{~F}+11 \mathrm{R}$ & 353 & $353 \mathrm{bp}$ \\
\hline H2O(NEGATIVE CONTROL) & No primer & No bands & No bands \\
\hline
\end{tabular}

fragments from varying weight of agarose gels to have eluted DNA samples for DNA sequencing and testing primer annealing. We had $15 \mu \mathrm{L}$ elute DNA of each sample resulted from this work and had more $8 \mu \mathrm{L}$ elute DNA from second clean up of elute DNA extraction (Table 6).

Basic Local Alignment Search Tool (BLAST) Searches. BLASTn was utilized for the alignment of all sequences of NA gene primers generated against a genbank consensus Avian Influenza Virus subtypes. BLAST analysis formed a robust alignment with the consensus sequence indicating $100 \%$ homology between 8F, 10F, 11R primers and Influenza A virus subtypes. In particular, $8 \mathrm{~F}$ primer was labeled in the alignment to correspond with other virus origin depicted $94 \%$ homology. It may be noted that $5 \mathrm{~F}$ primer appeared to be non-specific primer for all virus subtypes available on genbank. Further confirmation of sequence was required

Table 6 MinElute DNA from gel extraction

\begin{tabular}{ccc}
\hline Sample & Band (bp) & $\begin{array}{c}\text { Weight of } \\
\text { agarose gel (g) }\end{array}$ \\
\hline H6N5 A/Shearwater/Aust/72 & 360 & 0.2 \\
H6N5 A/Shearwater/Aust/72 & 200 & 0.3 \\
H6N5 A/Shearwater/Aust/72 & 219 & 0.3 \\
H6N5 A/Shearwater/Aust/72 & 300 & 0.3 \\
H6N5 A/Shearwater/Aust/72 & 353 & 0.2 \\
H6N5 A/Shearwater/Aust/72 & 353 & 0.4 \\
H6N5 A/Shearwater/Aust/72 & 169 & 0.2 \\
H7N7 A/Chicken/Victoria/1/85 & 353 & 0.3 \\
H12N9 A/RNStint/WA/5754/84 & 219 & 0.2 \\
H12N9 A/RNStint/WA/5754/84 & 353 & 0.2 \\
H12N9 A/RNStint/WA/5754/84 & 460 & 0.2 \\
\hline
\end{tabular}

using the outline in Table 7.

Phylogenetic Tree Development. Utilizing Clustal-X 1.83 for multiple alignments, it was possible to test variability for regions of 44 different AIV subtype sequences divided into 9 varied NA genes and bounded by NA pair of primer PCR products (Table 8). All trees developed underwent bootstrapping and Treeview programs to distinguish phylogenetic relationships between AIV subtypes and NA primers which randomly align into 0.1 distance matrices of 1000 frequency of each node or label. It was essential to analyze the bootstrap values and positions of sequences that were aligned or matched as well as mismatched or creating a gap (Fig 1-3).

Mutations in NA Primer PCR Products. The information shown in this table was based on scientific findings from Brown et al. (1998); Herlocher et al. (2003); Herlocher et al. (2004); De Jong et al. (2005); Jackson et al. (2005); Mai Le et al. (2005); Jackson et al. (2008); Stouffer et al. (2008). As can be seen, clinical mutations occurring in $8 \mathrm{~F}$ and $10 \mathrm{R}$ pair of primers at protein positions 274 ( $820-830$ amino acid positions) and 292 (870-880 amino acid positions) and 10F and 11R pair primers at protein positions 294 (880-890 amino acid positions).

\section{DISCUSSION}

Amplification of PB2 Gene H1N9/A/Shelduck/WA/ 1757/78 and H3N8/ A/Avian/669/WA/78 via Cloning into Escherichia coli Strain DH5 $\alpha$. Ligation PB2 gene into $E$. coli $\mathrm{dH} 5 \alpha$ cells were failed because $E$. coli $\mathrm{d} H 5 \alpha$ cells could 
Tabel 7 BLAST result homology $\%$ between NA primers and virus origin

\begin{tabular}{|c|c|c|}
\hline Primer & Nucleotide & Result homology \% \\
\hline $5 \mathrm{~F}$ & $\begin{array}{l}\text { CAY DS5 AAT GR5 ACM RT5 MA5 GA } \\
\text { (192 redundancy, } 48 \% \text { recombination) }\end{array}$ & $\begin{array}{l}100 \% \text { for other viruses and bacteria, such as HIV-1, } \\
\text { Herpesvirus, Bacillus, Canine distemper, } \\
\text { Streptococcus so } 5 \mathrm{~F} \text { primer was non-specific primer } \\
\text { for Influenza virus. }\end{array}$ \\
\hline $8 \mathrm{~F}$ & $\begin{array}{l}\text { GRA CHC ARG ART C5K MRT G } \\
\text { (192 redundancy, } 42 \% \text { recombination) }\end{array}$ & $\begin{array}{l}100 \% \text { for } \mathrm{H} 1 \mathrm{~N} 2, \mathrm{H} 3 \mathrm{~N} 2, \mathrm{H} 7 \mathrm{~N} 2, \mathrm{H} 4 \mathrm{~N} 6, \mathrm{H} 7 \mathrm{~N} 7, \mathrm{H} 5 \mathrm{~N} 7 \\
94 \% \text { for H4N6, H1N3, H3N3, H9N2, H6N6, H13N3, } \\
\mathrm{H} 3 \mathrm{~N} 2, \mathrm{H} 3 \mathrm{~N} 3, \mathrm{H} 1 \mathrm{~N} 2, \mathrm{H} 9 \mathrm{~N} 2, \mathrm{H} 7 \mathrm{~N} 3, \mathrm{H} 5 \mathrm{~N} 8, \mathrm{H} 3 \mathrm{~N} 6 \text {. }\end{array}$ \\
\hline $10 \mathrm{~F}$ & $\begin{array}{l}\text { TGY AGR GAY AAY TGG M55 GG } \\
\text { (32 redundancy, 35\% recombination) }\end{array}$ & $100 \%$ for $\mathrm{H} 3 \mathrm{~N} 2, \mathrm{H} 1 \mathrm{~N} 2$ \\
\hline $10 \mathrm{R}$ & $\begin{array}{l}\text { CC5 5KC CAR TTR TCY CTR CA } \\
\text { (32 redundancy, } 35 \% \text { recombination) }\end{array}$ & $\begin{array}{l}100 \% \text { for } \mathrm{H} 3 \mathrm{~N} 1, \mathrm{H} 11 \mathrm{~N} 1, \mathrm{H} 1 \mathrm{~N} 1, \mathrm{H} 9 \mathrm{~N} 1, \mathrm{H} 13 \mathrm{~N} 9 \text {, } \\
\mathrm{H} 11 \mathrm{~N} 9, \mathrm{H} 5 \mathrm{~N} 1, \mathrm{H} 2 \mathrm{~N} 1, \mathrm{H} 7 \mathrm{~N} 1, \mathrm{H} 2 \mathrm{~N} 9 \text {. }\end{array}$ \\
\hline $11 \mathrm{R}$ & $\begin{array}{l}\text { CCD ASA RTA 5CC 5GA CCA RT } \\
\text { (24 redundancy, 30\% recombination) }\end{array}$ & $100 \%$ for $\mathrm{H} 7 \mathrm{~N} 2, \mathrm{H} 6 \mathrm{~N} 2, \mathrm{H} 11 \mathrm{~N} 2, \mathrm{H} 9 \mathrm{~N} 2, \mathrm{H} 5 \mathrm{~N} 2$. \\
\hline
\end{tabular}

Table 8 Sequence names for clustalX 1.83 (shown in Fig 1-3)

\begin{tabular}{|c|c|}
\hline Na subtype & Sequence names of 44 different subtypes \\
\hline \multirow[t]{4}{*}{ N1 } & A/Dk/Indonesia/MS/2004(H5N1), A/duck/Korea/S17/03(H6N1), \\
\hline & A/turkey/Ontario/HR2/2000(H7N1), A/Aquatic Bird/Hong Kong/m603/98 (H11N1), \\
\hline & A/Duck/Shantou/2030/00(H9N1), A/Duck/Ohio/118C/93 (H1N1), \\
\hline & A/mallard/Alberta/47/98(H4N1), A/mallard/Stralsund/41-6/81(H2N1). \\
\hline \multirow[t]{4}{*}{$\mathrm{N} 2$} & A/Mallard/New York/6750/78 (H2N2), A/chicken/Guatemala/194573/02 (H5N2), \\
\hline & A/duck/Korea/S7/03(H3N2), A/chicken/HongKong/TP38/03(H9N2), \\
\hline & A/chicken/California/139/01(H6N2), (A/avian/NY/76247-3/00(H7N2), \\
\hline & A/duck/NC/91347/01(H1N2). \\
\hline \multirow[t]{3}{*}{ N3 } & A/chicken/British Columbia/04(H7N3), A/Blue-winged Teal/604/78 (H2N3), \\
\hline & A/Shearwater/Australia/75 (H5N3), A/black-headed gull/Sweden/2/99(H16N3), \\
\hline & $\mathrm{A} /$ tern/Astr/775/83(H3N3) \\
\hline \multirow[t]{2}{*}{ N4 } & A/gray teal/Australia/2/79(H4N4), A/ruddy turnstone/Delaware/67/98(H12N4), \\
\hline & A/Turkey/Ontario/6118/68 (H8N4) \\
\hline N5 & A/Shearwater/72 (N5), A/shearwater/australia/72 (H6N5) \\
\hline \multirow[t]{3}{*}{ N6 } & A/mallard/Alberta/42/77(H1N6), A/duck/England/56 (H11N6), \\
\hline & A/duck/NewZealand/31/76(H4N6), A/turkey/Minnesota/957/80(H6N6), \\
\hline & A/black-headed gull/Sweden/1/99(H13N6), A/pintail duck/Alberta/712/80(H3N6) \\
\hline N7 & A/chick/n/germany/49 (H10N7), A/FPV/Weybridge (H7N7), A/Mallard/64650/03(H5N7) \\
\hline \multirow[t]{2}{*}{ N8 } & A/Turkey/Canada/63(H6N8), A/Quail/Italy/1117/65 (H10N8), A/Guinea fowl/New York/4-3587/84 (H3N8), \\
\hline & A/Herring gull/DE/677/88 (H2N8), A/pintail/Alberta/207/99(H4N8), A/duck/NY/191255-59/02(H5N8) \\
\hline \multirow[t]{2}{*}{ N9 } & A/tern/Australia/G70C/75 (H11N9), A/ruddy turnstone/NJ/60/85 (N9), A/NWS/33HA- \\
\hline & A/tern/Australia/G70C/75NA (H1N9), A/teal/Alberta/16/97(H2N9) \\
\hline
\end{tabular}

Note: H11N6 and H10N8 created gaps in NA pair of primers (see Fig 1-3).

not be competent cells indicating mid-log suspension culture of $\mathrm{OD}_{600}$ for 3-4 hr was 1.3 (OD $_{600}$ should be 0.8-1.2 means $8-12.10^{8}$ cells $\left.\mathrm{mL}^{-1}\right)$. Thereby, low efficiency competent cells

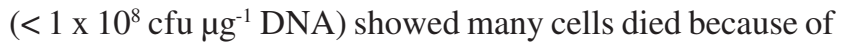
lack of food source and lots of toxic metabolites. In addition, we applied improperly less incubation time (1-4 h at room temperature) for optimal ligation. As a result, the transformation efficiency (TE) for E.coli $\mathrm{dH} 5 \alpha$ cells was either

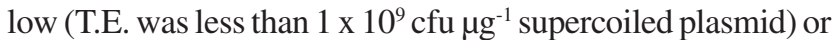
the cells did not grow well on agar plates. Consequently, we used another type of competent cells such as E. coli Top10 Cells from Invitrogen and the cloning experimentation was performed according to the manufacturer's instructions.

Amplification of PB2 Gene Segment DNA via Cloning into Top10 Cells. Generation of clones was required for future sequencing of the PB2 gene 6 Avian Influenza Virus (AIV) subtypes provided (H5N3, H6N5, H7N7, H11N6, H12N9 and H15N9 subtypes shown in Table 1). DNA cloning procedures including ligations, transformations, plasmid purifications and restriction enzyme digestions were mostly successful with insert DNA bands of the correct size resulting upon agarose electrophoresis analysis. UV analysis for other subtypes identified insert DNA products of expected sizes (full length
PB2 genes were detected at the large 986 bp product) shown in Fig 4-9. However, no visible bands of insert DNA for PB2 gene H12N9 clones 1-6 (Fig 10) appearing upon gel analysis of a potential problems with DNA samples following failed transformation with a lack of white bacterial colony growth on spread agar plates indicating DNA absence. The transformation efficiency (TE) of PB2 gene H12N9 was low (TE $=8 \times 10^{6}$ transformants/ $\mu$ g plasmid DNA while TE of these

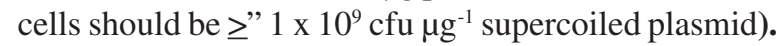

Determination of PB2 Gene Concentration. DNA concentration (Table 4) was determined with the assumption

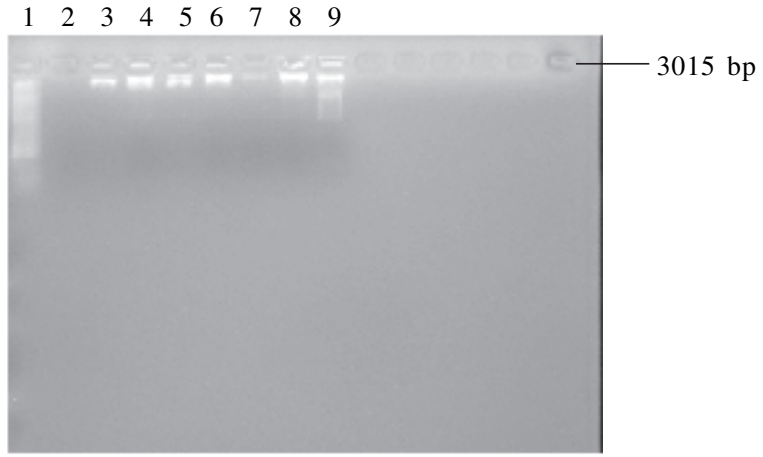

Fig 10 Analysis of H12N9 PB2 gene segment DNA PCR product. 
that double stranded DNA sample has a calculation absorbance from 2 to $100 \mathrm{ng} \mu \mathrm{L}^{-1}$ with upper limit to detect $3700 \mathrm{ng} \mu \mathrm{L}^{-1}$. The results indicated that H6N5 clone 6 and H12N9 clone 4 had much lower concentration than other

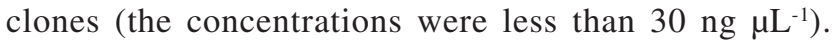
Consequently, these DNA sample may not be detected by gel electrophoresis after the utilization of restriction enzyme digestions. The determination of DNA concentration will be important for DNA dilutions of future work such as DNA sequencing, DNA annealing with universal HA primer designs, and DNA sampling to detect new diagnostic tools of influenza infection, virulence and pathogenesis.

PCR Amplification of NA Genes. Subtypes NA gene H6N5/A/Shearwater/Aust/72 were annealing with 8F and 10R pair of primers showing expected band of $219 \mathrm{bp}$, and $10 \mathrm{~F}$ and $11 \mathrm{R}$ pair of primers indicating desired band of $353 \mathrm{bp}$. On the other hand, NA gene H6N5/A/Sheartwater/72 was less accurate annealing with $5 \mathrm{~F}$ and $10 \mathrm{R}$ pair primers with varying bands of $200 \mathrm{bp}, 300 \mathrm{bp}$ and $400 \mathrm{bp}$ (Table 5). It is also important to note that $5 \mathrm{~F}$ and $10 \mathrm{R}$ pair of primers was not specific primers for Influenza A viruses as BLAST result homology $100 \%$ shown in Table 7. Another subtype NA gene H7N7/A/Chicken/Victoria/1/85 used as positive control was annealing with $10 \mathrm{~F}$ and $11 \mathrm{R}$ pair primers denoting expected band to be $353 \mathrm{bp}$.

Extraction of DNA Fragments from Agarose Gels. NA gene subtype H6N5/A/Sheartwater/72 was successfully extracted from isolation of expected band to be $219 \mathrm{bp}$ indicating matched annealing with $8 \mathrm{~F}$ and $10 \mathrm{R}$ primers and another band of $353 \mathrm{bp}$ showing correct annealing with $10 \mathrm{~F}$ and $11 \mathrm{R}$ primers. Specific DNA fragment of desired band (353 bp) was extracted from NA gene H7N7/A/Chicken/ Victoria/1/85 showing annealing with $10 \mathrm{~F}$ and $11 \mathrm{R}$ pair of primers. Another subtype was NA gene H12N9/A/RNStint/ WA/5754/84 denoting expected bands of each $219 \mathrm{bp}$ for $8 \mathrm{~F}$ and $10 \mathrm{R}$ primer annealing, $353 \mathrm{bp}$ for $10 \mathrm{~F}$ and $11 \mathrm{R}$ primer annealing and $460 \mathrm{bp}$ for $5 \mathrm{~F}$ and $10 \mathrm{R}$ primer annealing.

Basic Local Alignment Search Tool (BLAST) Searches. It can be shown that $5 \mathrm{~F}$ primer had 192 redundancies and $48 \%$ recombination and when $5 \mathrm{~F}$ primer paired with $10 \mathrm{R}$ primer which had 32 redundancies and 35\% recombination, the multiplicity of 5F and 10R pair of primers expected to be 6144 with $83 \%$ recombination. It may be noted that $8 \mathrm{~F}$ primer had 192 redundancies and $42 \%$ recombination and when $8 \mathrm{~F}$ primer paired with $10 \mathrm{R}$ primer which had 32 redundancies and $35 \%$ recombination, the multiplicity of $8 \mathrm{~F}$ and $10 \mathrm{R}$ pair of primers expected to be 6144 with $77 \%$ recombination. Of interest was $10 \mathrm{~F}$ and $11 \mathrm{R}$ pair of primers that $10 \mathrm{~F}$ primer had 32 redundancies with $35 \%$ recombination and $11 \mathrm{R}$ primer had 24 redundancies and $30 \%$ recombination, there by, when they paired the multiplicity became 768 with $65 \%$ recombination. The increased redundancy, multiplicity and recombination conferred problems, meaning that large amounts of primers would have to be utilized in order to anneal template DNA samples. Based on the analysis of homology, redundancy, multiplicity and recombination, it appeared that $10 \mathrm{~F}$ and $11 \mathrm{R}$ pair of primers was better than $8 \mathrm{~F}$ and $11 \mathrm{R}$ pair of primers. Moreover, $8 \mathrm{~F}$ and $11 \mathrm{R}$ pair of primers was much better than $5 \mathrm{~F}$ and $10 \mathrm{R}$ pair of primers. For this reason, $10 \mathrm{~F}$ and $11 \mathrm{R}$ pair of primers and $8 \mathrm{~F}$ and $10 \mathrm{R}$ pair of primers will be important to utilize as universal primers for NA gene AIV subtype detections.

Phylogenetic Tree Development. The first tree produced aligned 5F and 10R pair of primers with AIV subtypes successfully sequenced (Fig 1). Upon analysis, it appeared that bootstrap values of 9 NA gene AIV subtypes ranged between 332 and 954 (from $33.2 \%$ to $95.4 \%$ ) and there was no gap in sequence positions. As a result, N1, N2, N3, N4, N5, N6, N7, N8 and N9 were aligned or clustal within each subtype. In addition, $5 \mathrm{~F}$ primer seemed to remain similar to $\mathrm{N} 3$ subtype with shortest distance of $422(42.2 \%)$ bootstrap values. 10R primer indicated closely linked to N5 appearing shortest distance of 492 (49.2\%) bootstrap value.

Looking at AIV aligned subtypes in fig $2,8 \mathrm{~F}$ and $10 \mathrm{R}$ pair of primers showed bootstrap values ranged between 226 and 992 (from $22.6 \%$ to $99.2 \%$ ) with two gaps in N8 and N6. When analyzing tree in fig 2 consisting of two gaps, clearer pathways emerged with clear indication that N8 (H10N8) was aligned with N5 showing 583 (58.3\%) bootstrap value and was also aligned with its own N8 subtype denoting 964 (96.4\%) bootstrap value. Moreover, N6 (H11N6) was aligned with N9 indicating $372(37.2 \%)$ bootstrap value and was also aligned with its own N6 subtype appearing 285 (28.5\%) bootstrap value. Consequently, only N1, N2, N3, N4, N5, N7 and N9 were aligned within each subtype. Furthermore, $8 \mathrm{~F}$ primer appeared to remain closely related to N9 with $728(72.8 \%)$ bootstrap value while $10 \mathrm{R}$ primer indicated similar to appearing N4 with $811(81.1 \%)$ bootstrap value.

Fig 3 indicated the phylogenetic relationship of NA gene AIV subtypes with $10 \mathrm{~F}$ and $11 \mathrm{R}$ pair of primers. This tree depicted bootstrap values ranged between 825 and 994 (from $82.5 \%$ to $99.4 \%$ ) with a gap in N8. When analyzing this tree consisting of a gap, accurate indication that N8 (H10N8) was aligned with N5 showing $274(27.4 \%)$ bootstrap value and was also aligned with N8 occurring $826(82.6 \%)$ bootstrap value. Consequently, N1, N2, N3, N4, N5, N6, N7 and N9 were aligned within each subtype. Furthermore, $10 \mathrm{~F}$ and $11 \mathrm{R}$ pair of primer linked similarly to N1 with 464 (46.4\%) bootstrap value.

The resultant primers were designed in conjunction with high bootstrap value of sequences found in multiple numbers of the NA gene family. That is, $10 \mathrm{~F}$ and $11 \mathrm{R}$ pair of primers showed the highest bootstrap value $(99.4 \%)$ followed by $8 \mathrm{~F}$ and $10 \mathrm{R}$ pair of primers $(99.2 \%)$, then, $5 \mathrm{~F}$ and $10 \mathrm{R}$ pair of primers $(95.4 \%)$. Since sequence alignment was rarely perfect, the primers were degenerate to permit at sequence positions of low matches or creating gaps. Once aligned, regions of high aligned sequences bounded by NA primers were analyzed for the appropriateness for essential primer utilizations. For this reason, $8 \mathrm{~F}$ and $10 \mathrm{R}$ pair of primers and $10 \mathrm{~F}$ and $11 \mathrm{R}$ pair primers will be able to identify variable NA gene families of AIV subtypes concomitantly with the detection of any mutations occurring in these primers.

Mutations in NA Primer PCR Products. Of interest were clinical mutations occurring in $8 \mathrm{~F}$ and $10 \mathrm{R}$ pair of primers at protein positions 274 (820-830 amino acid positions) and 292 (870-880 amino acid positions) and $10 \mathrm{~F}$ and $11 \mathrm{R}$ pair primers at protein positions 294 (880-890 amino acid positions). 
Referring to Table 3, these mutations gave rise to antiviral drug resistance (Oseltamivir). It appeared that $8 \mathrm{~F}$ and $10 \mathrm{R}$ primers contained a tyrosine residue at position 274 (Y) indicating that a possible shift from $\mathrm{H}$ (histidine) to $\mathrm{Y}$ (tyrosine) is required to block neuraminidase inhibitor (Oseltamivir), as well as an arginine (R)-to-lysine (K) change at position 292. It can be noted that $10 \mathrm{~F}$ and $11 \mathrm{R}$ pair of primers had a serine $(\mathrm{S})$ to asparagine $(\mathrm{N})$ substitution at position 294 to confer Oseltamivir resistance. Thus, $8 \mathrm{~F}$ and $10 \mathrm{R}$ pair of primers and $10 \mathrm{~F}$ and $11 \mathrm{R}$ pair of primers consisted of mutations that may have a higher ability to promote virulence as a result of drug resistance pathway.

\section{ACKNOWLEDGEMENTS}

This work was funded by BioChip Innovations, the CEED program and was supported by CSIRO.

\section{REFERENCES}

Alvarez AC, Brunck MEG, Boyd V, Lai R, Virtue E, Chen W, Bletchly C, Heine HG, Barnard RT. 2008. A broad spectrum, one step reverse transcription PCR amplification of the neuraminidase gene from multiple subtypes of influenza A virus. J Virol 5:77.

Barr IG. 2005. The evolution of H5N1 avian influenza viruses in South East Asia. In: Proceedings of the $3^{\text {rd }}$ Australian Virology Group Meeting. Cowes Phillip Island, Australia, Dec 9-12, 2005. p 39.

Brown IH, Harris PA, McCauley JW, Alexander DJ. 1998. Multiple genetic reassortment of avian and human influenza $A$ viruses in European pigs, resulting in the emergence of an $\mathrm{H} 1 \mathrm{~N} 2$ virus of novel genotype. J Gen Virol 79:2947-55.

De Jong MD, Thanh TT, Khanh TH, Hien VM, Smith GJD, Chau NV, Cam BV, Qui PT, Ha DQ, Guan Y, Peiris JSM, Hien TT, Farrar J. 2005. Oseltamivir resistance during treatment of influenza A (H5N1) infection. New England J Med 353:2667-72.

Hatta M, Gao, P, Halfmann P, Kawaoka Y. 2001. Molecular basis for high virulence of Hong Kong H5N1 influenza A viruses. Science 293:1840-2.

Herlocher ML, Truscon R, Fenton R, Klimov A, Elias S. 2003. Assessment of development of resistance to antivirals in the ferret model of influenza virus infection. J Infectious Diseases 188:135561.

Herlocher ML, Yen HL, Hoffmann E, Matrosovich MN, Monto AS. 2004. Influenza viruses resistant to the antiviral drug oseltamivir: transmission studies in ferrets. J Infectious Diseases 190:1627-30.

Hoffmann EG, Neuman Y, Kawaoka Y, Hobom G, Webster RG. 2000. Characterization of the influenza A virus gene pool in avian species in southern China: was H6N1 a derivative or a precursor of H5N1. J Virol 74:6309-15.
Hulse DJ, Webster RG, Russel RJ, Perez DR. 2004. Molecular determinants within the surface proteins involved in the pathogenicity of H5N1 influenza viruses in chickens. J Virol 78:9954-64.

Jackson D, Barclay W, Zurcher T. 2005. Characterization of recombinant influenza $\mathrm{B}$ viruses with key neuraminidase inhibitor resistance mutations. J Antimicrobial Chemo 55:162-9.

Jackson D, Lamb RA. 2008. The influenza A virus spliced messenger RNA M mRNA3 is not required for viral replication in tissue culture. J Gen Virol 89:3097-101.

Katz JM, Lu X, Tumpey TM, Smith CB, Shaw MW, Subbarao K. 2000. Molecular correlates of influenza A H5N1 virus pathogenesis in mice. J Virol 74:10807-10.

Komadina N, Hurt AC, Shaw R, Brown L, Barr IG. 2005. Genetic analysis of recent highly pathogenic avian influenza (HPAI) strains from SE Asia. In: Proceedings of the $3^{\text {rd }}$ Australian Virology Group Meeting. Cowes Phillip Island, Australia, Dec 9-12, 2005. p 81.

Lamb RA. 2007. Structural basis of viral infection: lessons from myxovirus. Curr Opin Struct Biol 17:427-36.

Lamb RA, Krug RM. 1996. Orthomyxoviridae: the viruses and their replication $3^{\text {rd }}$ ed. Philadelphia: Lippincott-Raven.

Mai Le Q, Kiso M, Someya K, Sakai YT, Nguyen TH, Nguyen KHL. 2005. Isolation of drug-resistant H5N1 virus. Nature 437:1108.

Mitnaul LJ, Matrosovich MN, Castrucci MR, Tuzikov AB, Bovin NV, Kobasa D, Kawaoka Y. 2000. Balanced hemagglutinin and neuraminidase activities are critical for efficient replication of influenza A virus. J Virol 74:6015-20.

Moscona A. 2005. Oseltamivir resistance-disabling our influenza defenses. New England J Med 353:2633-6.

Moscona A. 2008. Medical management of influenza infection. Annu Rev Med 59:397-413.

Peters PH, Moscona A, Schulman KL, Barr CE. 2008. Study of the impact of oseltamivir on the risks for pneumonia and other outcomes of influenza 2000-2005. Medscape J Med 10:131.

Russel CA, Jones TC, Barr IG, Cox NJ, Garten RJ, Gregory V, Gust ID, Hampson AW, Hay AJ. 2008. The global circulation of seasonal influenza A viruses. Science 320(5874):340-346.

Stouffer AL. 2008. The interplay of functional tuning, drug resistance and thermodynamic stability in the evolution of the M2 proton channel from the influenza A virus. Structure 16:1067-76.

Vesudevan M, Lai R, Barnard RT. 2005. Australian influenza A phylogeny and analysis of putative risk indicator codons in the gene segment encoding PB2. In: Proceedings of the $3^{\text {rd }}$ Australian Virology Group Meeting. Cowes Phillip Island, Australia, Dec 912, 2005. p 76.

Watanabe T, Watanabe S, Kim JH, Hatta M, Kawaoka Y. 2008. Novel approach to the development of effective H5N1 influenza A virus vaccines: use of M2 cytoplasmic tail mutants. J Virol 82:2486-92.

Wright PF, Webster RG. 2001. Fields virology. In: Knipe DM, Howley PM, editors. Philadelphia: Lippincott-Raven. p 1533-79. 